\title{
Induksi dan Multiplikasi Tunas Alfalfa (Medicago sativa L) secara In Vitro untuk Penyediaan Bibit Tanaman Pakan Ternak
}

\author{
(Shoot Induction and Multiplication of Alfalfa (Medicago sativa L) \\ through In Vitro Culture)
}

Sajimin, Purwantari ND

Balai Penelitian Ternak, PO Box 221, Ciawi, Bogor 16002

djiemin@yahoo.com

\begin{abstract}
Multiplication of alfalfa through in vitro culture is an alternative technique to conventional one to solve the problem on forage without seed production. An experiment was done to obtain the best culture media for shoot induction and multiplication of alfalfa. This research was conducted at the tissue culture in BB Biogen laboratory. The seed of alfalfa was used which was cultured on MS media and seeds were then transferred on seven sterilization treatment BA $0.5 \mathrm{mg} / 1+\mathrm{GA}(0.1 ; 0.5$; and $1.0 \mathrm{mg} / \mathrm{l})$ media germination. Shoot multiplication of alfalfa were eight treatment on growth were MS + BA $(0.0 ; 0.5$; and $1.0 \mathrm{mg} / \mathrm{l})$ with combination with thidiazuron (TDZ) $(0.0 ; 3.0$; and 5.0 $\mathrm{mg} / \mathrm{l})$. Results showed that conducted the highest number of shoot multiplication of alfalfa was obtained on the media containing BA $0.5 \mathrm{mg} / \mathrm{l}$ and TDZ $3.0 \mathrm{mg} / \mathrm{l}$ (9.6 shoots and shoot length was observed at average $14.6 \mathrm{~mm}$ and a number of leaf 17). Induction and multiplication the shoot was an important early stages to multiply the seed of alfalfa in in vitro culture.
\end{abstract}

Key Word: Alfalfa, Shoot, Induction, Multiplication

\begin{abstract}
ABSTRAK
Perbanyakan tanaman alfalfa melalui kultur in vitro merupakan salah satu cara untuk mengatasi permasalahan yang dihadapi pada perbanyakan benih yang tidak menghasilkan biji. Penelitian ini bertujuan mendapatkan media yang cocok untuk induksi pertunasan dan multiplikasi tunas pada tanaman alfalfa. Penelitian dilaksanakan di Kultur Jaringan BB Biogen. Bahan eksplan yang digunakan adalah biji alfalfa yang dikulturkan pada media MS dengan perlakuan sterilisasi tujuh perlakuan pertunasan kombinasi BA $0,5 \mathrm{mg} / \mathrm{l}+\mathrm{GA}(0,1 ; 0,5$; dan $1,0 \mathrm{mg} / \mathrm{l})$. Multiplikasi tunas alfalfa terdiri atas delapan perlakuan zat pengatur tumbuh, yaitu MS + BA $(0,0 ; 0,5 ;$ dan 1,0 $\mathrm{mg} / \mathrm{l})$ dikombinasikan dengan thidiazuron (TDZ) $(0,0 ; 3,0$; dan 5,0 mg/l). Hasil penelitian menunjukkan bahwa hasil multiplikasi tunas pada media MS yang mengandung 0,5 mg/l BA dan $3,0 \mathrm{mg} / \mathrm{l} \mathrm{TDZ}$ menghasilkan jumlah tunas terbanyak $(9,6$ tunas, tinggi $14,6 \mathrm{~mm}$ dan jumlah daun 17 helai/tanaman). Induksi dan multiplikasi tunas merupakan tahapan awal yang penting untuk memperbanyak benih alfalfa secara kultur in vitro.
\end{abstract}

Kata Kunci: Alfalfa, Tunas, Induksi, Multiplikasi

\section{PENDAHULUAN}

Alfalfa (Medicago sativa L) termasuk tanaman leguminosa perenial dan merupakan hijauan pakan yang populer sebagai pakan ternak. Tanaman tersebut merupakan tanaman asli Asia dan Iran yang telah berkembang secara luas pada berbagai lingkungan. Alfalfa seringkali dipanen untuk dijadikan pakan ternak dan sebagai tanaman obat dan memiliki sistem perakaran yang dalam, sehingga toleran pada kondisi kering (Ehsanpour \& Razavizadeh 2005). 
Tanaman bercabang dan membentuk rhizome, membutuhkan sinar matahari dan kadar kapur yang cukup, tahan temperatur tinggi tetapi tidak tahan kelembaban tinggi dan penggembalaan berat. Menurut Radovic et al. (2009) alfalfa memerlukan drainase baik, pH 6,5 atau lebih dengan kesuburan tanah yang baik. Alfalfa dapat beradaptasi pada daerah kering (curah hujan $200 \mathrm{~mm} / \mathrm{tahun}$ ) atau daerah basah $2.500 \mathrm{~mm} /$ tahun dengan drainase yang baik. Batang tanaman mendatar, menanjak sampai tegak, berkayu di bagian dasar, cabang-cabang di bagian dasar dan menanjak setinggi 30-120 cm, satu tangkai (petiole) berdaun tiga (trifoliat), panjang daun $5-15 \mathrm{~mm}$, berbulu pada permukaan bawah, tangkai daun berbulu, bunga berbentuk tandan yang rapat berisi 10-35 bunga, mahkota berwarna ungu atau biru jarang yang berwarna putih (Mannetje \& Jones 2000). Menurut Hoy et al. (2002) alfalfa adalah leguminosa yang biasa tumbuh di daerah temperate (sedang) dan berumur 8-10 tahun.

Berdasarkan potensi biomassa budidaya tanaman alfalfa sebagai pakan ternak menguntungkan. Produsen terbesar alfalfa di dunia adalah Amerika Serikat diantaranya California, South Dacota dan Wisconsin. Tanaman alfalfa telah ditanam lebih dari 80 negara atau sekitar 35 juta ha (Steinbeck 2007). Menurut Radovic et al. (2009) produksinya mencapai 80 ton/ha bahan segar dan 20 ton/ha bahan kering dengan kandungan protein tinggi. Marcovic et al. (2007) menyatakan bahwa alfalfa juga mengandung asam amino serta kaya vitamin serta unsur mineral penting untuk pertumbuhan dan perkembangan ternak. Kemampuan tanaman alfalfa mengikat $\mathrm{N}$ dari udara sebesar 7,85-10,35 g/m² (Matensson \& Ljunggren 1984).

Fiksasi $\mathrm{N}$ tersebut berdampak positif pada lingkungan yang dapat menanggulangi polusi udara serta memperlambat kelarutannya dalam tanah sehingga meningkatkan bahan organik sehingga dapat menurunkan kebutuhan $\mathrm{N}$ tanaman. Tanaman demikian tidak memerlukan pupuk nitrogen bahkan menyumbangkan $\mathrm{N}$ dalam tanah. Beberapa hasil penelitian, lahan yang setelah ditanami alfalfa selama empat tahun kemudian ditanami jagung menjadi lebih efektif dalam penggunaan urea, yaitu hanya berkisar 33\% (Russelle 2004). Alfalfa juga masih mampu mengikat nitrogen walaupun adanya tekanan lingkungan tanah yang kapasitas lapang tanahnya 30 dan 60\% (Freyer 2004). Hal inilah yang membuat tanaman ini dapat dijadikan tanaman penyubur tanah dan berpotensi untuk dikembangkan sebagai pakan ternak di Indonesia karena memiliki keunggulan tersebut dibandingkan dengan tanaman pakan jenis leguminosa lainnya. Hal ini mendorong upaya perluasan penanaman alfalfa di Indonesia untuk memenuhi kebutuhan.

Tanaman alfalfa yang telah ditanam tidak menghasilkan biji, sehingga untuk tanam kembali perlu impor. Untuk menghasilkan biji tanaman alfalfa memerlukan serangga dalam proses penyerbukan sejenis lebah madu. Menurut Kemp \& Bosch (2000) dan Brunet \& Stewart (2010) untuk menghasilkan biji alfalfa memerlukan serangga seperti lebah madu jenis Apis mellifera dan Megachile rotundata yang ada di California dan Pasifik Tenggara serta anatomi bunga. Serangga tersebut perlu dikelola untuk menjadi penyerbuk bunga. Untuk mengatasi ketersediaan bibit perlu perbanyakan secara vegetatif. Melalui makalah ini, dipelajari perbanyakan tanaman secara kultur jaringan untuk penyediaan bibit secara vegetatif.

\section{MATERI DAN METODE}

\section{Induksi pertunasan alfalfa melalui kultur in vitro menggunakan biji}

Penelitian ini dilakukan dengan tahapan sterilisasi benih dengan diawali pencucian sampai bersih. Selanjutnya disterilkan dengan tahapan sterilisasi (St) 1-4 menggunakan 
benlate $60 \%$, alkohol $70 \%, \mathrm{HgCl}_{2} \mathrm{0,2} \%$, klorok $30 \%$ dan klorok $20 \%$ dengan perbedaan waktu perendaman (Tabel 1).

Tabel 1. Perlakuan sterilisasi biji alfalfa untuk mendapatkan eksplan

\begin{tabular}{lccccc}
\hline \hline \multirow{2}{*}{ Perlakuan } & \multicolumn{5}{c}{ Bahan sterilisasi biji } \\
\cline { 2 - 6 } & Benlate (\%) & Alkohol 70\% & $\mathrm{HgCl}_{2}$ 0,2\% & Klorok 30\% & Klorok 20\% \\
\cline { 2 - 6 } & 60 & 10 & - & 7 & 5 \\
\hline St 1 & 60 & 10 & - & 5 & 5 \\
St 2 & 60 & 10 & 3 & - & 5 \\
St 3 & 60 & 10 & 3 & - & 3 \\
St 4 & & & & &
\end{tabular}

St: Sterilisasi

Bahan untuk induksi tunas adalah zat pengatur tumbuh (ZPT) dari golongan sitokinin yaitu benzylaminopurin (BA) dan media dasar murashigi dan skoog (MS). Hasil sterilisasi terbaik digunakan untuk mendapatkan kecambah yang selanjutnya ditanam dalam media MS ditambahkan GA dengan perlakuan perendaman giberelin acid (RGA) dan tanpa perendaman (NRGA) dengan tujuh perlakuan dan diulang 10 kali: (1) MS + BA $(0,0)+$ GA 0,1 mg/l; (2) MS + BA $(0,0)+$ GA 0,5 mg/l; (3) MS + BA $(0,0)+$ GA 1,0 mg/l; (4) $\mathrm{MS}+\mathrm{BA}(0,5)+\mathrm{GA} 0,1 \mathrm{mg} / \mathrm{l} ;(5) \mathrm{MS}+\mathrm{BA}(0,5)+\mathrm{GA} 0,5 \mathrm{mg} / \mathrm{l} ;(6) \mathrm{MS}+\mathrm{BA}(0,5)+$ GA $1,0 \mathrm{mg} / \mathrm{l}$; dan (7) MS + BA $(0,0)+$ GA $0,0 \mathrm{mg} / \mathrm{l}$. Parameter yang diamati persentase daya kecambah biji.

\section{Induksi multiplikasi tunas melalui organogenesis (epikotil)}

Biji alfalfa sebagai bahan eksplan yang sudah disterilisasi diinduksi (ditumbuhkan) ke dalam media tanpa ZPT media dasar MS (hasil induksi pertunasan melaui kultur in vitro dari biji). Setelah tumbuh menjadi tanaman lengkap, selanjutnya dilakukan pemotongan bagian-bagian vegetatif menjadi stek mikro. Media perlakuan dibuat dengan menggunakan media dasar MS lalu ditambahkan ZPT sesuai dosis perlakuan. Inokulum tersebut selanjutnya ditanam pada media perlakuan kemudian dilakukan pengamatan tiap minggu dengan penambahan BA 0,5 + GA 0,5 mg/l hingga membentuk tunas. Kecambah yang sudah terbentuk kemudian dipindahkan pada media baru untuk menginduksi multiplikasi tunas melalui jalur organogenesis. Bahan tanaman yang digunakan adalah tunas terminal (epikotil). Formula media untuk menginduksi pertunasan melalui jalur organogenesis dari ekplan kecambah adalah MS + BA $(0,0 ; 0,5$; dan 1,0 mg/l) dikombinasikan dengan TDZ $(0,0 ; 3,0 ;$ dan $5,0 \mathrm{mg} / \mathrm{l})$.

Rancangan Penelitian yang digunakan dalam penelitian ini adalah Rancangan Acak Lengkap terdiri atas 8 perlakuan yaitu berbagai komposisi media: (1). MS + 0,0 mg/l BA + 3,0 mg/l TDZ; (2) MS + 0,0 mg/l BA + 5,0 mg/l TDZ; (3) MS + 0,5 mg/l BA + 0,0 mg/l TDZ; (4) MS + 1,0 mg/l BA + 3,0 mg/l TDZ; (5) MS + 1,0 mg/l BA + 5,0 mg/l TDZ; (6) $\mathrm{MS}+1,0 \mathrm{mg} / \mathrm{l} \mathrm{BA}+0,0 \mathrm{mg} / \mathrm{l} \mathrm{TDZ}$; (7) $\mathrm{MS}+0,5 \mathrm{mg} / \mathrm{l} \mathrm{BA}+3,0 \mathrm{mg} / \mathrm{l} \mathrm{TDZ}$; dan (8) MS + $0,5 \mathrm{mg} / \mathrm{l} \mathrm{BA}+5,0 \mathrm{mg} / \mathrm{l} \mathrm{TDZ}$.

Peubah yang diamati adalah jumlah tunas dan tinggi tunas $(\mathrm{mm})$, jumlah daun serta visual biakan, sedangkan persentase bertunas dan waktu bertunas diamati setiap tiga hari dan hasil pengamatan waktu bertunas. Setiap perlakuan ada 10 ulangan, masing-masing ulangan merupakan satu unit percobaan. Data hasil pengamatan dianalisis dan dilanjutkan dengan uji beda nyata terkecil. 
Eksplan yang sudah ditanam diletakkan di dalam rak kultur dengan intensitas penyinaran 1.000 luks lama penyinaran selama 16 jam untuk proses fotosintesis dalam sehari untuk inkubasi pertumbuhan.

\section{HASIL DAN PEMBAHASAN}

\section{Induksi pertunasan alfalfa melalui kultur in vitro menggunakan biji}

Tanaman alfalfa yang digunakan pada kegiatan ini berasal dari biji yang dikecambahkan pada kultur media. Sebelum dikecambahkan, perlakuan biji alfalfa disterilkan terlebih dahulu kemudian direndam pada RGA dan NRGA.

Hasil perlakuan sterilisasi biji terbaik kemudian digunakan untuk mengecambahkan biji yang direndam dalam giberelin acid untuk mendapatkan planlate sebagai materi induksi tunas dan hasilnya tertera pada Tabel 2.

Hasil perlakuan sterilisasi 1-4 tahap biji alfalfa diperoleh hasil yang optimum dan semua perlakuan tidak terjadi kontaminasi (Tabel 2). Hal ini menunjukkan bahwa sterilisasi menggunakan alkohol 70\% (10 menit) dan klorok 20\% (3-5 menit) telah mencegah tumbuhnya bakteri sehingga tidak terjadi kontaminasi pada eksplan. Penggunaan klorok 30\% tidak berpengaruh pada biji, terlihat pada dosis tinggi, perkecambahan menjadi rendah. Namun, jika dikombinasi dengan klorok 20\%, DK meningkat. Artinya yang berperan adalah klorok 20\%. Dengan lama penggunaan klorok $20 \%$ dikurangi ternyata daya kecambah meningkat dari $4 \%$ menjadi $33 \%$ dan planlate hidup $66 \%$.

Tabel 2. Kondisi biji alfalfa pada perlakuan sterilisasi

\begin{tabular}{|c|c|c|c|c|c|c|c|c|c|}
\hline \multirow{3}{*}{$\mathrm{P}$} & \multicolumn{5}{|c|}{ Bahan sterilisasi biji } & \multicolumn{4}{|c|}{ Kondisi biji alfalfa pada media } \\
\hline & \multirow{2}{*}{$\begin{array}{c}\text { Benlate } \\
(\%)\end{array}$} & A & B & $\mathrm{C}$ & $\mathrm{D}$ & AA & $\mathrm{BB}$ & $\mathrm{CC}$ & DD \\
\hline & & \multicolumn{4}{|c|}{-------------------- menit-------------------- } & \multicolumn{4}{|c|}{--------------- \% --------------- } \\
\hline St 1 & 60 & 10 & - & 7 & 5 & - & 100 & 0 & 0 \\
\hline St 2 & 60 & 10 & - & 5 & 5 & - & 96 & 4 & 2 \\
\hline St 3 & 60 & 10 & 3 & - & 5 & - & 92 & 8 & 4 \\
\hline St 4 & 60 & 10 & 3 & - & 3 & - & 34 & 66 & 33 \\
\hline
\end{tabular}

P: Perlakuan; St: Sterilisasi; A: Alkohol 70\%; B: $\mathrm{HgCl}_{2}$ 0,2\%; C: Klorok 30\%; D: Klorok 20\%; AA: Kontaminasi; BB: Mortalitas (mati); CC: Survival (hidup); DD: Daya kecambah

Pada Tabel 3 terlihat bahwa dengan perendaman GA kemampuan daya kecambah biji alfalfa lebih besar dibandingkan tanpa perendaman GA. Perlakuan kontrol mempunyai daya kecambah signifikan lebih tinggi $(75,0-87,5 \%)$ dibandingkan dengan perlakuan lainnya kecuali pada perendaman dengan GA 1,0 mg/l non-signifikan.

Pada Tabel 4 terlihat pertumbuhan tunas dari biji tanpa perendaman GA pada umur 28 hari terendah $12 \mathrm{~mm}$ pada perlakuan $\mathrm{MS}+0,5 \mathrm{mg} / \mathrm{l} \mathrm{BA}+1,0 \mathrm{mg} / \mathrm{l} \mathrm{GA}$ dan tidak berbeda nyata dengan kontrol $(\mathrm{P}>0,05)$. Pertumbuhan tertinggi $21,8 \mathrm{~mm}$ pada perlakuan $\mathrm{MS}+1,0$ $\mathrm{mg} / \mathrm{l}$ GA. Hasil penelitian ini nampaknya GA berperan pada pertumbuhan daripada BA. Selain itu, terlihat bahwa pertumbuhan tunas dengan perendaman (RGA) lebih tinggi daripada tanpa perendaman (NRGA). Hasil pengamatan pada hari ke-28, tinggi eksplan bervariasi, menunjukkan adanya pengaruh dari media tanam. Menurut Agustin \& Aprilianti (2011), giberelin mengontrol perkecambahan biji berbagai jenis tumbuhan di alam dan dapat menggantikan peran cahaya dan suhu dalam meningkatkan perkecambahan. Oleh karena itu, perlakuan kontrol (media MS) yang tanpa giberelin lebih 
rendah dibandingkan pada perlakuan penambahan zat pengatur tumbuh seperti yang tertera pada Tabel 4.

Tabel 3. Rata-rata daya kecambah biji alfalfa pada perbedaan media tanam dengan perlakuan perendaman giberelin acid (RGA) dan non perendaman giberelin acid (NRGA)

\begin{tabular}{ccccc}
\hline \hline \multicolumn{3}{c}{ Media tanam $(\mathrm{mg} / \mathrm{l})$} & \multicolumn{2}{c}{ Persentase daya kecambah selama 14 hari $(\%)$} \\
\hline MS & BA & GA & NRGA & RGA \\
\hline MS & 0,0 & 0,1 & $16,0^{\mathrm{b}}$ & $60,0^{\mathrm{a}}$ \\
MS & 0,0 & 0,5 & $8,0^{\mathrm{a}}$ & $60,0^{\mathrm{a}}$ \\
MS & 0,0 & 1,0 & $48,0^{\mathrm{c}}$ & $76,0^{\mathrm{ab}}$ \\
MS & 0,5 & 0,1 & $4,0^{\mathrm{a}}$ & $72,0^{\mathrm{a}}$ \\
MS & 0,5 & 0,5 & $20,0^{\mathrm{b}}$ & $68,0^{\mathrm{a}}$ \\
MS & 0,5 & 1,0 & $16,0^{\mathrm{b}}$ & $68,0^{\mathrm{a}}$ \\
MS & 0,0 & 0,0 & $75,0^{\mathrm{d}}$ & $87,5^{\mathrm{b}}$ \\
\hline
\end{tabular}

MS: Murashigi dan Skoog; BA: Benzylaminopurin; GA: Giberelin acid; NRGA: Tanpa perendamana GA; RGA: Dengan perendaman GA; Angka yang diikuti huruf sama pada kolom sama tidak beda nyata $\mathrm{P}>0,05$

Tabel 4. Rata-rata pertumbuhan tunas pada perlakuan media MS

\begin{tabular}{|c|c|c|c|c|c|c|c|c|}
\hline \multirow{2}{*}{\multicolumn{3}{|c|}{ Media tanam ( mg/l) }} & \multicolumn{6}{|c|}{ Tinggi (mm) eksplan alfalfa pada perlakuan biji } \\
\hline & & & \multicolumn{3}{|c|}{ NRGA hari ke- } & \multicolumn{3}{|c|}{ RGA hari ke- } \\
\hline MS & BA & GA & 14 & 21 & 28 & 14 & 21 & 28 \\
\hline MS & 0,0 & 0,1 & 1,3 & 16,0 & $17,0^{\mathrm{ab}}$ & 3,0 & 17,8 & $22,0^{\mathrm{b}}$ \\
\hline MS & 0,0 & 0,5 & 1,0 & 17,0 & $17,0^{\mathrm{ab}}$ & 2,8 & 21,8 & $22,8^{\mathrm{b}}$ \\
\hline MS & 0,0 & 1,0 & 2,2 & 19,4 & $21,8^{\mathrm{b}}$ & 3,8 & 15,4 & $18,6^{\mathrm{b}}$ \\
\hline MS & 0,5 & 0,1 & 2,0 & 16,0 & $17,0^{\mathrm{ab}}$ & 2,8 & 19,0 & $20,0^{b}$ \\
\hline MS & 0,5 & 0,5 & 1,3 & 15,7 & $15,7^{\mathrm{ab}}$ & 3,4 & 18,8 & $18,8^{b}$ \\
\hline MS & 0,5 & 1,0 & 1,0 & 12,0 & $12,0^{\mathrm{a}}$ & 3,2 & 10,2 & $15,0^{\mathrm{a}}$ \\
\hline MS & 0,0 & 0,0 & 4,0 & 6,5 & $12,0^{\mathrm{a}}$ & 9,0 & 12,1 & $13,7^{\mathrm{a}}$ \\
\hline
\end{tabular}

MS: Murashigi dan Skoog; BA: Benzylaminopurin; GA: Giberelin acid; NRGA: Tanpa perendamana GA; RGA: Dengan perendaman GA; Angka yang diikuti huruf sama pada kolom sama tidak beda nyata $\mathrm{P}>0,05$

Pada perlakuan biji yang direndam GA 60 menit dan ditanam pada media MS terendah $13,7 \mathrm{~mm}$ pada perlakuan kontrol yang tidak berbeda $(\mathrm{P}>0,05)$ pada perlakuan MS $+0,5 \mathrm{mg} / \mathrm{l} \mathrm{BA}+1,0 \mathrm{mg} / \mathrm{l} \mathrm{GA}$. Pertumbuhan tertinggi $22,8 \mathrm{~mm}$ pada perlakaun $\mathrm{MS}+0,5$ $\mathrm{mg} / \mathrm{l} \mathrm{GA}$ atau lebih tinggi 42,3\% dari kontrol. Lebih tingginya pertumbuhan eksplan pada media yang ditambah zat pengatur tumbuh telah berpengaruh pada pemanjangan dan pembelahan sel. Hal ini terlihat pada 14 hari pertumbuhan masih rendah dan setelah 21-28 hari tinggi tunas meningkat secara nyata. Lebih cepat tumbuh adanya zat pengatur tumbuh mempengaruhi tumbuhnya tunas. Zat pengatur tumbuh berperan pada pertumbuhan dan morfogenesis dalam kultur sel, jaringan dan organ. Interaksi dan perimbangan antara zat pengatur tumbuh yang diberikan dalam media dan yang diproduksi oleh sel secara endogen akan menentukan arah perkembangan suatu kultur. Menurut Bey et al. (2006) peranan giberelin merupakan senyawa organik yang berperan dalam proses perkecambahan karena mengaktifkan reaksi enzimatik didalam benih sehingga metabolisme sel meningkat untuk pembentukan protocorm like bodies (plb). Kemudian 
Kusumo (1984) dan Asra (2014) mengemukakan GA merupakan zat pengatur tumbuh yang diperlukan pada proses perkecambahan. Pada pertumbuhan vegetatif perkembangan tanaman tergantung pada pembelahan sel, pembesaran dan deferensial. Zat pengatur tubuh ini merangsang aktivitas pembelahan sel pada daerah meristem batang dan kambium sehingga mempercepat tumbuhnya batang dan daun pada tanaman.

\section{Induksi multiplikasi tunas melalui organogenesis (epikotil)}

Hasil pengamatan induksi tunas alfalfa dari epikotil selama 12 minggu menunjukkan pertumbuhan tunas, penambahan jumlah tunas dan daun terjadi pada minggu kedua sampai minggu keenam dan kesebelas kemudian pertumbuhannya telah optimal.

Tabel 5. Rata-rata jumlah tunas, tinggi dan jumlah daun pada umur 11 minggu pada media tumbuh dari eksplan epikotil alfalfa

\begin{tabular}{lrrrl}
\hline \hline Media tumbuh & $\begin{array}{c}\text { Tinggi } \\
(\mathrm{mm})\end{array}$ & $\sum$ tunas & $\sum$ daun & Penampilan eksplan \\
\hline MS +3,0 mg/l TDZ & $13,0^{\mathrm{b}}$ & $3,3^{\mathrm{a}}$ & $5,3^{\mathrm{a}}$ & Hijau, normal, tunas rendah \\
MS + 5,0 mg/l TDZ & $10,3^{\mathrm{a}}$ & $4,3^{\mathrm{a}}$ & $4,4^{\mathrm{a}}$ & Hijau segar, daun normal \\
MS + 0,5 mg/l BA & $9,8^{\mathrm{a}}$ & $6,0^{\mathrm{b}}$ & $6,0^{\mathrm{a}}$ & Hijau segar, daun normal \\
MS +1,0 mg/l BA + 3,0 mg/l TDZ & $12,5^{\mathrm{ab}}$ & $3,8^{\mathrm{a}}$ & $8,2^{\mathrm{ab}}$ & Hijau, rendah \\
MS + 1,0 mg/l BA + 5,0 mg/l TDZ & $14,7^{\mathrm{b}}$ & $4,7^{\mathrm{a}}$ & $9,7^{\mathrm{b}}$ & Hijau, ramping \\
MS + 1,0 mg/l BA & $15,0^{\mathrm{b}}$ & $6,8^{\mathrm{b}}$ & $11,4^{\mathrm{b}}$ & Hijau, tunas normal \\
MS + 0,5 mg/l BA + 3,0 mg/l TDZ & $14,6^{\mathrm{b}}$ & $9,6^{\mathrm{c}}$ & $17,0^{\mathrm{c}}$ & Hijau, tunas beraturan \\
MS + 0,5 mg/l BA + 5 mg/l TDZ & $14,0^{\mathrm{b}}$ & $5,7^{\mathrm{ab}}$ & $9,0^{\mathrm{b}}$ & Hijau, tunas normal \\
\hline
\end{tabular}

MS: Murashigi dan Skoog; BA: Benzylaminopurin; TDZ: Thidiazuron; Angka yang diikuti huruf sama dalam kolom sama tidak beda nyata $\mathrm{P}>0,05$

Dari hasil analisa data terlihat bahwa daya multiplikasi eksplan alfalfa selama 11 minggu dengan tinggi tunas, jumlah daun dan jumlah tunas pada perbedaan media tumbuh berbeda nyata antar perlakuan. Jumlah tunas dan jumlah daun tertinggi pada perlakuan media dengan penambahan ZPT BA 0,5 mg/l + TDZ 3,0 mg/l. Perbedaan tersebut terlihat dari kemampuan multiplikasi tunas pada umur 6-7 minggu baru mulai tumbuh rata-rata 11 tunas dan minggu ke-11 menjadi 9,6 tunas dan 17 daun. Demikian juga penampilan tunas yang tumbuh normal (munculnya tunas nyata). Hal ini terlihat dari pertumbuhan daun yang normal dan jumlah tunasnya jelas.

Hasil multiplikasi tunas alfalfa dari epikotil terlihat bahwa setelah minggu ke-11 ratarata jumlah tunas tidak ada penambahan. Selain itu, penampilan eksplan telah menunjukkan daunnya mulai pucat dan layu. Keadaan demikian eksplan dianggap tidak mampu bermultiplikasi dengan baik (penambahan tunas telah optimum). Hasil penelitian induksi tunas dengan perbedaan konsentrasi zat pengatur tumbuh mempengaruhi terbentuknya tunas. Menurut Lestari (2011) pada perbanyakan tanaman melalui kultur jaringan, peranan zat pengatur tumbuh sangat penting untuk mengontrol organogenesis dan morfogenesis dalam pembentukan dan perkembangan tunas. Hasil yang sama juga di laporkan Sajimin et al. (2015) bahwa kombinasi zat pengatur tumbuh BA dan TDZ jumlah tunas pada Leucaena KX2 yang terbentuk meningkat. Menurut Wattimena (1988) dan Lizawati et al. (2009) kombinasi BA dan TDZ mempunyai aktivitas yang tinggi sehingga memacu pembelahan sel yang cepat. 


\section{KESIMPULAN}

Dari hasil penelitian disimpulkan bahwa induksi tunas alfalfa dari biji yang dikecambahkan dengan perlakuan perendaman GA 1,0 mg/l menghasilkan daya kecambah $76 \%$. Induksi tunas melalui epikotil telah terjadi multiplikasi optimum pada perlakuan media tumbuh BA 0,5 mg/l dan TDZ 3,0 mg/l dengan jumlah tunas 9,6; tinggi 14,6 mm dan jumlah daun 17 per kultur dengan tunas beraturan.

\section{DAFTAR PUSTAKA}

Agustin EK, Aprilianti P. 2011. Pengaruh pemakaian hormon tumbuh GA3 (giberelin acid) terhadap perkecambahan dan pertumbuhan biji Verscffeltia splendida HAWendl. J Biol Res. 7A:157-160.

Asra R. 2014. Pengaruh hormon GA3 terhadap daya kecambah dan vigoritas Calopogonium caeruleum. Biospecies. 7:29-33.

Bey Y, Syafii W, Sutrisna. 2006. Pengaruh pemberian giberelin (GA3) dan air kelapa terhadap perkecambahan bahan biji anggrek bulan (Phalaenopsis amabilis BL) secara in vitro. J Biogenesis. 2:41-46.

Brunet J, CM Stewart. 2010. Impact of bee species and plant density on alfalfa pollination and potential for gene flow. Hindawi Publishing Corporation Psyche. p. 7.

Ehsanpour AA, Razavizadeh R. 2005. Effect of UV-C radiation on drought tolerance of alfalfa (Medicago sativa) callus. Pakistan J Biol Sci.8:1221-1224.

Freyer B. 2004. Biological nitrogen fixation of different legume species under water stress. Universiats of Natural Resourcehes and Applied Life Sciences Institute of Organic Farming Gregor Mendel Viena.

Hoy DM, Mooere KJ, George JR, Brummer EC. 2002. Alfalfa yield and quality as influenced by establishment method. Agronomi J. 94:65-71.

Kemp WP, Bosch J. 2000. Development and emergence of the alfalfa pollinator Megachile rotundata (Hymenoptera: Megachilidae). Ann Entomol Soc Am. 93:904-911.

Kusumo S. 1984. ZPT. Jakarta (Indonesia): Yasa guna.

Lestari EG. 2011. Peranan zat pengatur tumbuh dalam perbanyakan tanaman melalui kultur jaringan. J Agrobiogen. 7:63-68.

Lizawati, Novita T, Purnamaningsih R. 2009. Induksi dan multiplikasi tunas jarak pagar secara in vitro. J Agronomi Indonesia. 37:78-85.

Mannetje L, Jones RM. 2000. Sumber daya nabati Asia Tenggara. Bogor (Indonesia): PT Balai Pustaka.

Markovic J, Radovic J, Lugic Z, Sokolovic D. 2007. The effect of development stage on chemical composition of alfalfa leaf and steam. Biotechnology in animal husbandry. 23.

Matensson AM, Ljunggren HD. 1984. Nitrogen fixation in an establishing alfalfa (M. sativa L) ley in Sweden, estimated by three different methods. Appl Environ Microbiol. 48:702-707.

Radovic J, Sokovic D, Markovic J. 2009. Alfalfa most important perennial forage legume in animal husbandry. Biotechnol Anim Husb. 25:465-475.

Russele M. 2004. The environmental impacs of N2 fixaation by alfalfa. In: Steenback J, editor. Proc Natinal Alfalfa Symposium. San Diego (US): Wikipedia.

Sajimin, Purwantari ND, Sukmadjaja D. 2015. Induksi dan multiplikasi tanaman pakan ternak Leucaena KX2 secara in vitro. J Pastura. 4:83-87. 
Steinbeck J. 2007. Alfalfa. wikipedia the free encyclopedia [Internet]. Available from: http://en. wikipedia.org/wiki/alfalfa.

Wattimena GA. 1988. Zat pengatur tumbuh tanaman. Bogor (Indonesia): Institut Pertanian Bogor.

\section{DISKUSI}

\section{Pertanyaan}

Bagaimana cara memperoleh benih afalfa? Apakah hasil kultur jaringan sudah ditanam ke lahan?

\section{Jawaban}

Benih diperoleh secara vegetatif, karena di Indonesia afalfa tidak memproduksi benih. Bila ingin memperolehnya dapat diimpor. Benih hasil kultur jaringan belum di kembangkan di lahan (kebun rumput). 